ingenious types of machinery which have been designed for the soldering of parts in the motor-car radiator, and in the closing of tin plate cans, now produced in thousands of millions a year, are described. The compositions and physical properties of solders of representative grades are discussed and the reasons for the suitability of each kind for special purposes are shown. The importance of using the right type of flux is explained and practical details of the fluxing and tinning of a large number of metals and alloys are given. Not the least valuable portion of the bulletin is the appendix, in which are given references to a large number of the more important books, papers and specifications dealing with solders and the production of soldered joints.

\section{Braking Efficiency of Modern Motor-Cars}

AN abstract of a speech made by Prof. R. A. Moyer at the Annual Safety Congress, held at the Iowa State College, has been issued by Science Service, Washington, D.C. Prof. Moyer considers that on ordinary roads the present-day braking power of motor-cars when driven at their highest speeds is insufficient, and that they are decidedly unsafe. Safety lies mainly in providing low stopping distances. To provide the same stopping distance when travelling at 60 miles an hour as at 40 miles an hour requires brakes two and a half times as powerful. In Prof. Moyer's opinion, to maintain traffic speeds at about 45 miles an hour on open stretches of road would eliminate many of the risks arising from high speed. A study of traffic statistics shows that half the risk of accident would be eliminated if cars were forbidden to run at more than 55 miles an hour. If speeds greater than this are necessary, it would be far cheaper and probably equally safe to use an aeroplane. Prof. Moyer points out that Sir Malcolm Campbell needed a 2,500 horse-power motor to average $\mathbf{3 0 0}$ miles an hour on the salt beds of Utahprobably the most perfect race course in the world. On the other hand, an aeroplane with a 1,000 horsepower motor can reach 350 miles an hour in the air.

\section{The British Accumulator Industry}

WHEN the National Grid was established in Great Britain in 1926 and the Electricity Commissioners adopted alternating current as the standard for distribution, many thought that it would affect adversely the electric accumulator industry. In an address delivered to the Institution of Electrical Engineers by E. C. McKinnon on October 22, it is pointed out that this is not the case. The industry is flourishing, and accumulators have rendered practicable many new electrical applications. For submarines they are essential, and the evolution of the submarine battery in thirty-five years has led to increasing its average life threefold and trebling its capacity for a given volume. Since the first automobile self-starter battery came into service in 1911, numerous current consuming 'gadgets' have boen added to the electrical equipment of the car, but in spite of this the present-day starter battery is much lighter, occupies much less space and gives a long life. Like the submarine, batteries for air- craft have called for much ingenuity in design. The cells for a large submarine may weigh $1 \frac{1}{2}$ tons each and their number ranges from 100 to more than 300 . Each cell has a volume of about 20 cubic feet and has to be lowered intact into the submarine. An aeroplane battery has to be much lighter, its usual weight being about 46 pounds and its volume about 700 cubic inches. To me日t the demands of aerobatics it must be absolutely unspillable in the inverted position. This is done by an ingenious hydrostatic device, and not by using a jellified electrolyte. There is a large demand for accumulators for automatic telephone purposes and for train 'lighting and cooking'. One of the widest applications for batteries nowadays is for emergency and standby purposes. A battery can ensure continuity of illumination for traders during busy periods, when a 'black-out' would be serious, and in hospitals. It is interesting to notice also that for many auxiliary services in connexion with the National Grid supply, there is a considerable demand for accumulators.

\section{Japan and Electric Communication}

Electrical communication industries are developing very rapidly in Japan. There are a million telephones in use, and two million homes have radio receiving sets. The Institute of Telephone and Telegraph Engineers has now five thousand members, and publishes a valuable technical journal every month. It has been decided to increase its usefulness by publishing every quarter an English edition of it. In the first English journal, the president of the Institute, Mr. T. Akiyama, says that their present knowledge of the technique of electrical communications has been obtainod largely from abroad, and that it is their duty to bring to the notice of foreign countries their own achievements in research and so repay the friendship shown to them through many years. By so doing it is hoped to contribute to the general advance of civilisation. It is stated that limited land and over-population have placed Japan in a position in which the nation cannot exist on agriculture alone; it is forced to turn to manufacturing industry for its welfare. At the present time, approximately 40 per cent of the Japanese population is engaged in commerce and industry. Japan is the boundary line between Asia and the Pacific Ocean. It is the duty of Japan to provide national and international communication networks so as to help to harmonise the Oriental and the Western civilisations. The development of radio communication in Japan has been largely due to their own initiative, and practically all the transmitting apparatus is of their own manufacture. There are twenty-five broadcasting stations which are run by a company under the supervision of the Government. They are all interconnected by wiro lines. The Japanese director-gonoral of onginoering says that their ideal is to help the fusion of cultures by keeping in constant touch with the other nations of the world. The journal, Nippon Electrical Communication Engineering, is a useful contribution to technical literature. 